\title{
Breves Palavras Acerca do Iluminismo e o
}

\section{Direito}

\author{
Plínio Melgaré \\ Mestre em Ciências Jurídico-Filosóficas (Universidade de \\ Coimbra) e Professor de Filosofia do Direito e História do \\ Pensamento Jurídico (Universidade Federal do Rio Grande do Sul).
}

Resumo:

O Iluminismo: suas principais características, o desenvolvimento da razão humana, o fenômeno da secularização, a autonomia individual e as alteraçôes ocorridas no mundo do direito. A conseqüente reconstrução do paradigma do direito natural e a adoção do método demonstrativo. Odistanciamentodo Direito Romano e Communis Opinio Doctorum alinhados ao novo postulado racional e a consolidação das codificaçóes. O direito português em face do Iluminismo: a Lei da Boa Razão e os Estatutos da Universidade de Coimbra que, por meio de estudantes brasileiros, influenciaram a culturajurídica pátria.

Abstract:

The lluminism: its mains characteristics, the development of the human reason, the phenomenon of secularization, the individual autonomy and the alterations that have occurred in the world of law. The consequent reconstruction of the paradigm of the natural law and the adoption of the demonstrative method. The aloofness of the Roman Law and the Communis Opinio Doctorum aligned to the new rational postulate and the consolidation of the codifications. The Portuguese Law in face the Iluminism: the Law of the Good Reason and the Statutes of the Coimbra University that, through the brazilian students, influenced the motherland legal culture.

\section{SUMÁRIO:}

InTROduÇÃo - Aspectos Gerais - Códigos JusRacionalistas - CORTE COM A Tradição Jurídica (Communis Opinio Doctorum e o Direito Romano) - O Período Iluminista no Direito Português - Apreciaçōes Finais

"Olluminismoéa saída do homem do estado deminoridade que ele deveimputar a si mesmo. (...). Sapere aude! Tem a coragem de servir-te de tua própria inteligência! Esse é olema do Iluminismo" - Emmanuel Kant 


\section{INTRODUÇÃO}

O propósito deste trabalho é consignar algumas considerações sobre o direito no período do Iluminismo. Sabemos que foi uma época onde profundas alterações, nos mais diversos campos do saber e da cultura humana, foram efetivadas. E o direito, alheio a estas mudanças, não ficou. Ao contrário, na seara do pensamento jurídico e do direito ocorreram modificaçóes importantes que o afetaram sobremaneira, a ponto de projetar influências percebidas mesmo após o final do Iluminismo.

Desse modo, partimos de aspectos gerais do referido período, o chamado Século das Luzes. Destacamos - e não poderíamos deixar de fazer, sob pena de comprometermos seriamente o trabalho - a (re)compreensão e o primado da razão humana. Assim, consideramos as conseqüências que a crença na razão impóe ao fenômeno jurídico. Tecemos comentários também sobre as codificaçōes que marcaram a época, em especial o Code Civil de 1804.

Na seqüência, focalizamos a distinção que se opera no campo das fontes jurídicas e a ruptura existente com o pensamento anteriormente estabelecido. Notadamente, $\mathrm{o}$ corte efetuado com o direito romano e a communis opinio doctorum. Observa-se que este corte referido ocorre sempre tendo como pano de fundo a razão humana. $\mathrm{E}$ isso demonstramos no corpo do trabalho.

Por derradeiro, olhamos para o direito português e as influências acarretadas pelo movimento iluminista, conduzindo nossos estudos até a reforma efetivada no ensino universitário, com o surgimento dos novos Estatutos da Universidade de Coimbra.

Assim foi pensado o trabalho.

\section{ASPECTOS GERAIS}

O século XVIII é aquele marcado pela influência do Iluminismo. Em Portugal, contudo, tal período fez sentir-se por volta da segunda metade do referido século, conforme constataremos no transcorrer do trabalho.

Caracterizar o indigitado período, objeto de estudo deste trabalho, com suas características conformadoras do pensamento jurídico, certamente, não é tarefa das mais fáceis, eis que encontramos diversos modelos, vertentes, tendências que, inclusive, apresentam fatores próprios em diversos países do continente europeu. ${ }^{1}$ Desse modo, a homogeneidade não pode ser colocada como matriz do Iluminismo setecentista. Luís CABRAL DE MONCADA, um autor nomeadamente dedicado a estudar - e o fez de modo profundo-o periodo, assim se expressou: "Ochamado lluminismo estálonge de ter sido um movimento uno na Europa. Há, por assim dizer, vários Iluminismos nos diversos países europeus,

\footnotetext{
${ }_{1}^{1}$ Assim, pode-se caracterizar distintamente um Iluminismo na França, outro na Inglaterra, na Itália, Alemanha, cada qual com peculiaridades próprias.
} 
nos quais, sobre uma unidade mais profunda de certas características comuns vieram-se instalarse também muitas características próprias, provenientes de muitas diversidades de Cultura e de tradição de toda a ordem" $(1949,06) .{ }^{2}$ Com efeito, o "Século das Luzes", movimento que adquire relevo no período setecentista, não se configura como um sistema fechado de idéias, sendo, em verdade, um difuso movimento humano-cultural, em que se desenvolve "la lotta della ragione contro 1 ' autorità come lotta della luce contro le tenebre: donde il nome di illuminismo"(FAssò: 2001, 194).

Contudo, a mencionada heterogeneidade de caracteres não implica que não se possa estabelecer traços comuns, essenciais e convergentes. $\mathrm{E}$ um desses elementos identificadores, trata de um superlativo desenvolvimento da habilidade racional do homem. Logo, ainda que genericamente, é adequado considerarmos como sendo a época da razão - una, imutável - e do racionalismo.

Tal característica, que tem seus albores no Século XVII, preponderando no século seguinte, provoca uma relevante alteração no âmbito e na história da compreensão jurídica. Nesse norte, sobressai a doutrina cartesiana e o abalo sofrido pela até então reinante autoridade da Antigüidade Clássica. De fato, RENÉ DesCARTES(1596-1650), há de ser sublinhado, não projetou a elaboração de um sistema jurídico. Entretanto, a essência de seu pensamento confrontava diretamente supostos que serviam de base do pensamento medievo. Por conseguinte, frente a toda e a máxima autoridade dada aos textos, bem como a relevância das opinióes reinantes, impunha-se, de agora em diante, a análise crítica, e, ante à particularidade da casuística, princípios e postulados gerais (CoING: 1996, 104).

Outro fator a ser gizado no período moderno-iluminista é a sua forte carga, base antropológica. Com isso, fazemos menção ao entendimento que o ser humano passa a fazer de si mesmo. Destacamos, nesse âmbito, a autonomia do homem, é dizer, o corte efetivado com uma pressuposta e transcendentalmente existente ordem, acentuando a razão ${ }^{3}$ como elemento fundamentante da ação e do saber do homem. Por esse iter, a liberdade como que reencontra sua raiz primitiva, de ato de desvinculação, de independentizar-se dos vínculos, de negar e refutar toda e qualquer organização social estribada em uma relação de privilégios entre a autoridade e a verdade. De fato, "a luta da independência individual pela eliminação dos vínculos de subordinação pessoal, pela autonomização do indivíduo, é ao mesmo tempo a luta contra a afirmação de uma verdade pública única e vinculante para todos"(BARCELLONA: 1989, 46).

Rigorosamente, no período que estamos a considerar, evidencia-se uma radical distinção em relação àquela a postura conformadora do temperamento humano tão próprio da Idade Média. Lá, encontrava-se o homem condicionado, vinculado a leis exteriores. $\mathrm{O}$ homem era um ser passivo que ainda não tinha descoberto seu espírito crítico. Em conformidade com KANT, o Iluminismo corresponderia a uma crise de crescimento, a

\footnotetext{
${ }^{2}$ No mesmo sentido, ver o posicionamento de GuIDo AstuTI, no seu texto intitulado "O Absolutismo Esclarecido em Itália e o Estado de Polícia", in Poder e Instituições na Europa do Antigo Regime, Fundação Calouste Gulbenkian, Lisboa: 1984.
} 
uma vontade de afastar-se da infância e, "se, nas épocas precedentes, ohomem se mantivera sob tutela, fora por culpa própria: não tivera a coragem de se servir da razão; tivera sempre necessidade de um mandamento exterior" (apud HAZARD: 1989, 40).

É certo, contudo, que o período medievo não teve seu ciclo terminado gratuitamente, por obra do acaso. Com efeito, salientamos causas e fatos objetivos determinantes do fim desse período. Elencamos, sem a pretensão de sermos taxativos, os seguintes fatos: a invenção da imprensa que proporcionou o espraiar das novas idéias; os descobrimentos, que colocaram o homem em contato com outros povos; e o natural desenvolvimento comercial, bem como a teoria de COPÉRNICO, a demonstrar o movimento da Terra em torno do Sol, o qual aquilatamos sua importância e seus efeitos trazendo à baila as palavras de BERTOLT BRECHT, em seu texto intitulado Circo de Massas: "A descoberta (...) que aproxima o homem do animal ao afastá-lo dos astros, que manda o homem girar com o seu globo à volta do Sol, o arranca do centro e o atira para o monte dos figurantes(...)" (1998, 57).

Destarte, sobretudo a partir do período setecentista, forja-se uma penetrante oposição, contraste com o período histórico antecedente. Para ilustrarmos tal assertiva, trazemos à baila as expressóes de P. HAZARD: "a hierarquia, a disciplina, a ordem, que a autoridade se encarregara de assegurar, e os dogmas que regulam firmemente a vida, tais são os valores amados pelos homens do século XVII. Constrangimento, autoridade, dogmas, tais são, em contrapartida, os valores rejeitados pelos homens do século $X V \mathrm{III}$, seus sucessores imediatos. Os primeiros são cristãos, os outros anti-cristãos; os primeiros vivem à vontade numa sociedade dividida em classes desiguais, os segundos sonham apenas com a igualdade; os primeiros crêem no direito divino, os segundos no direito natural' (apud HESPANHA, 1984, 253). ${ }^{4}$ Sem embargo, duas características marcantes identificaram o período medievo: o domínio da consciência humana por uma revelação divina e a percepção cristão-ocidental de constituir, sobretudo, uma unidade religiosa, que também política, mas que tinha por seu fundamento a religião. ${ }^{5}$

No período da Ilustração, encontramos o homem emancipado. E o termo "emancipação" fora empregue, primeiramente, com o sentido da liberdade de um povo em se reger. Na Alemanha, em 1792, corresponderia a dizer que o homem possuía em si próprio o sentido de orientação do seu próprio comportamento. Posteriormente, assume um caráter extensivo a toda a humanidade, "destinatária de uma acção libertadora, pois não há maior crime do que manter os homens na condição de animais domésticos" (BAPTISTA PEREIRA: 1990, 95).

\footnotetext{
${ }^{3}$ Assim pode ser entendida a razão iluminista: "É como uma soberana que, tendo alcançado o poder, toma a resolução de ignorar as províncias onde sabe que nunca poderá reinar totalmente. (...). Talé o papel da razão: em presença do obscuro, do duvidoso, lança-se ao trabalho, julga, compara, utiliza uma medida comum, descobre, pronuncia-se. (...). Da razão depende toda a ciência e toda a filosofia. (...). A razão basta a si própria: quem a possui e exerce sem preconceitos jamais se engana: (...) ela segue infalivelmente o caminho da verdade" (HAZARD: 1989, 35-37 passim).

"Parece-nos que o citado autor refere-se, em sua última distinção, quando fala em "direito natural», ao direito natural moderno, ou seja, àquele que tem como fundamento último a razão, ao jusracionalismo.

${ }^{5}$ Nesse sentido, ver FASSÒ: 2001, 05.
} 
Igualmente, há o fenômeno, no sentido de algo manifestado à consciência, da secularização. Aquando da sua primeira utilização, significava "expropriação de bens e domínios eclesiásticos" (BAPTISTA PEREIRA: 1990, 39). Na verdade, estávamos frente ao surgimento do poder civil, entendido pela sua autonomia de ação e, igualmente, a um homem compreendido autonomamente. Um homem achando-se autor da história, responsável por ele mesmo, pensando por si próprio, almejando uma razão humana de caráter universal. Sem embargo, através do processo da secularização, o mundo passa a integrar a esfera da compreensão racional do ser humano. A religião e também a Igreja deixam, como fundamento, de ser elementos que projetam a sociedade. ${ }^{6} \mathrm{O}$ mundo pertence a uma esfera de projeção racional da compreensão humana.

Temos, agora, um homem responsável por si próprio, pelo seu destino, reconhecendo e descobrindo sua autonomia, e sendo sujeito da sua própria existência. Um ser humano com espírito crítico e emancipado. Os valores componentes do mundo humano deixam de ser vistos como projeção de uma expressão de vontade suprema, oriunda de uma divindade, e passam a ser de responsabilidade do próprio homem. Por certo, "o homem distanciou-se de Deus - pois se Deus é transcendente ao homem, a história é, pastuladamente, da responsabilidade deste último" (BRONZE: 1997, 311).?

$O$ poder e sua vontade constituem uma prerrogativa individual. A até entáo organização hierárquica estabelecida na sociedade feudal como algo natural é abandonada pelo homem, que promove e implementa uma nova ordem em nome do indivíduo. De fato, a concepção da emancipação do homem amplia e estende suas conseqüências até momentos posteriores. Nessa linha, registramos: "o pensamento e a acção dos séculos XIX eXX são governados pela ideia de emancipação da humanidade. (...). Oprogresso das ciências, das técnicas, das artes e das liberdades políticas emancipará a humanidade inteira da ignorância, da pobreza, da incultura, do despotismo, e não fará apenas homens felizes, mas, nomeadamente graças à Escola, cidadãos esclarecidos, senhores do seu próprio destino"(LYOTARD: 1999, 101). Pois tal é o momento do jusracionalismo, em que o jurídico, assim como o político e também a moral, apresentam uma redução ao método das ciências demonstrativas. Houve a preconização de um direito eterno e imutável, tendo como pilar a razão humana, válido para todos e em todas as épocas. Delineia-se um conhecimento jurídico consoante um novo ideário ético, qual seja o de uma sociedade construída e organizada de acordo com a razáo universal e válida para todos e em todos os tempos e lugares. Encontra-se, pontualmente, uma clara distinção com a compreensão que se tinha a respeito do direito na Idade Média, eis que, no período medievo, o direito assentava e emanava de uma vontade deificada, divina. Por conseguinte, a idéia primeira e nuclear do direito natural repousava na idéia de Deus.

\footnotetext{
${ }^{6}$ Até então, lembramos, a verdade era que a ordem, o poder fundava-se na religião, enquanto que, na cultura secularizada, como fundamento, a antropologia substitui a Religiāo. Outrossim, a secularização vincula-se ao conceito de "soberania e razão-de-Estado e à reforma protestante, que levaram à separação entre Direito e Teologia" (LAFER: 1999, 38)

7 Convém lembrarmos a observação feita por HANNAH ARENDT, ao afirmar que a emancipação e a secularização apresenta um "desvio, não necessariamente de Deus, senão de um Deus que era o Pai dos homens no céu" $(1998,14)$.
} 
Impende acentuar que o direito natural moderno instrumentalizou o Direito Positivo. A lei natural brotava da razão e iluminava as leis emanadas da autoridade civil. De fato, registramos que "natural significava racional, e sobretudo não-sobrenatural; eo chamado a natureza era em realidade um chamado à consciência crítica do homem (...), da razão humana, a medida de toda a verdade em todos os campos"(FAssò: 2001, 194). Uma razão subjetiva e crítica, assim como um racionalismo humanista e antropocêntrico. A concepção racionalista, na esteira dos ensinamentos de NORBERTO BOBBIO, pode ser caracterizada por estas duas asserções fundamentais:

- o mundoé um sistema ordenado regido por leis universais e necessárias

- o homem é um ser racional, ou seja, dotado de uma faculdade que lhe permite compreenderaquelas leis

Centrado nessas assertivas, prossegue o mencionado autor: "A ciência, em definitivo, consiste no descobrimento e formulação de leis que estão já na natureza e que como tais são imutáveis e necessárias; em conseqüência os resultados obtidos, suas verdades, têm caráter de definitivo" (apud OrTEGA: 1998, 25). Assim, desde logo, temos uma razão referente ao sujeito, crítica, e um racionalismo com raízes humanistas ${ }^{8}$ e antropocêntricas.

Salientando outra característica geral, surge, nesse período, a concepção individualista e liberal tanto do Estado quanto do direito. $O$ direito natural apresenta como sustentáculo direitos originários do indivíduo, nascidos antes mesmo de qualquer vinculação social ou civil. A idéia que se passa a ter do Estado impóe, como reivindicação, a liberdade do indivíduo. Em conformidade com CABRAL DE MONCADA, arrolamos duas causas dessas transformações: ideológicas e políticas. Como ideológica assinala-se um certo espírito individualista, vicejante desde o Renascimento e o período barroco, animado pelas guerras religiosas desenvolvidas nos séculos XVI e XVII. Como causa política, apresenta a Revolução Inglesa de 1688, bem como "o sentimento de liberdade de consciência, reclamada pelos dissidentes calvinistas franceses, e sobretudo ingleses, depois das lutas religiosas dos séculos XVIe XVI"' (1995, 202 e 203). Por via de conseqüência, o individualismo "acabou por ser expressão político-social da liberdade moderno-iluminista"(CASTANHEIRA NEVES: $1976,05)$, e tal individualismo distingue, sobremaneira, o homem moderno do homem pré-moderno.

Voltando nossas reflexões à razão, táo caracterizadora do momento, releva observar que passou a ser a derradeira instância mobilizada pelo homem, sendo força motora de suas ações. A razão iluminista seria aquela instância que albergaria as verdades eternas, livre da sujeição das verdades postas pela revelação teológica, sendo restringida à experiência. Distingue-se, dentre toda a variável gama de possibilidades dos princípios fundamentais e indiscutíveis das religiōes, das crenças morais, um termo não sujeito a

${ }^{8}$ Como exemplo do cariz humanista, citamos, no âmbito do Direito Penal, a obra de Cesare Beccaria, "Dei Delitti e delle Pene", do ano de 1764. 
mudanças, que, em sua unidade e consistência, afirmam a própria essência da razão (CASSIRER: 1997, 23). Ainda em CASSIRER, encontramos que a razão do século XVIII perde a característica de ser uma idéia inata e, por via de consequiência, anterior a experiência, podendo ser melhor compreendida se pensada como uma maneira de aquisição - e não propriamente uma posse. Dessarte, torna-se "o poder original e primitivo que nos leva a descobrir, a estabelecer e a consolidar a verdade" $(1973,32) .{ }^{9}$ Essa "razão", genuína e intensamente potencializada no campo das ciências naturais, contudo, foi trazida para o pensamento jurídico-político. É, portanto, um racionalismo originário do modelo utilizado pelas ciências naturais.

Isso posto, salientamos a construção de sistemas racionais e logicamente coerentes, estruturados em cadeias meramente dedutivas. A raiz dessa origem, baseada na referida ciência natural, trouxe relevantes conseqüências e influências para o pensamento jurídico. Com efeito, o mesmo pensamento demonstrativo utilizado para as ciências naturais foi transposto para o universo jurídico. ${ }^{10} \mathrm{~A}$ ciência jurídica integrou-se ao universo das matérias alheias à experiência, vinculando-se àquelas dependentes de definiçóes. $O$ direito não dependeria dos fatos, mas de provas e demonstrações racionais. Acreditava-se que, permeado por postulados últimos da razão, fosse possível edificar sistemas prontos, acabados, para qualquer campo do saber humano. Nesse aspecto, reside outra significativa distinção posta pelo projeto iluminista com a maneira de pensar anterior.

Exsurge um sistema jurídico marcadamente axiomático, racional, pleno. E o modo invocado pelo pensar estrutura-se em um silogismo formal, onde a lei passa a ser a premissa maior, o fato a premissa menor, alcançando-se, dedutivamente, a sentença. É o processo de aplicação subsuntiva da lei a imperar e coordenar o raciocínio jurídico, acarretando um racionalismo divorciado completamente das questões práticas. ${ }^{11}$ Criava-se, prévia e especulativamente, um sistema para, em um segundo momento, ser aplicado na resolução dos concretos casos que emergiam da vida quotidiana.

Sem embargo, o homem moderno-iluminista impunha sua liberdade racional implementando seus interesses. Por certo que haveria interesses divergentes e antagônicos entre si, tornando-se necessário o estabelecer de uma certa ordem. $\mathrm{O}$ paradigma vislumbrado para estremar uma sociedade calcada no indivíduo deveria respeitar e afirmar a liberdade e a igualdade dos indivíduos, determinando-se pela vontade dos próprios

\footnotetext{
${ }^{9}$ llustramos, outrossim, a razão iluminista com o exemplo utilizado pelo Professor CASTANHEIRA NeVES. Entāo, segundo o romancista italiano AlbERTo Morávia refere, há dois modos de construir uma estrada: o modo humano, que tem na estrada um instrumento ao serviço do homem e que portanto deve se adaptar à paisagem humana, respeitando-a; e o modo racional, que, aproveitando os conhecimentos da geometria, une dois pontos através de uma linha reta, sacrificando tudo o que de humano ali porventura exista, com o intuito de encontrar a rapidez, a maneira mais diligente $(1995,18)$.

${ }^{10}$ A corroborar nossa afirmação, registramos: "Séduits par les premiers succés des sciences physiques et éblouis par la perfection des raisonnements logiques et mathematiques, les hommes (...) poursuivent activement le projet de construire une science naturelle du droit, qui atteindrait à un degré de certitude égal, et peut-être même supérieur, à celui des mathématiques" (FRYDMAN: 1998, 41).

11 Por todo o visto e ponderado, adotamos as seguintes palavras: "Le casus n'est plus le point de départ de toute discussion, mais au contraire le point d'arrivée d'une longue chaine de syllogismes Qui conduit successivement de la simple raison au droit naturel, de celui-ci aux lois positives générales, et enfin de ces derniéres à leurs applications particulières" (FRYDMAN: 1998, 44).
} 
indivíduos componentes da sociedade. Então, sobressai o modelo contratualista. Importa ressaltar essa nuança do período iluminista para chegarmos a idéia conformadora da lei da época, e, igualmente, a compreensão acerca do direito. Pois, somente será considerado direito aquele que for determinado pelo contrato social. Conseqüentemente, o direito encarregar-se-ia de harmonizar as liberdades de todos e de cada indivíduo. ${ }^{12} \mathrm{E}$ às leis caberia o papel definidor das regras de convivência dos elementos integrantes desta nova sociedade. Delineada por esse contorno, a lei visava tão-somente a compatibilização dos mais variados interesses daqueles atores sociais. Eram, portanto, regras formais, abstratas e gerais, não definindo o conteúdo das liberdades individuais, nem fazendo referências materialmente éticas. ${ }^{13}$

O racionalismo iluminista enxergava no indivíduo um elemento destinado a compor e operacionalizar uma estrutura maior, qual seja a sociedade. E, para efetivar o adequado funcionamento da estrutura social, faz-se necessário o posicionamento correto de cada indivíduo. Assim, encontramos José VIRíssimo Alvares da Silva a pronunciarse: "a sociedade he uma máquina complicada, que trabalha com tantas moles quantos são os individuos de que se compóem", e, prosseguindo, "mais precisa huma razão iluminada que saiba guiar tudo a seus justos fins" (GOMES DA SILVA: 1990, 340). Nessa direção, surge a legislação como sendo uma obra que sintetiza toda a sabedoria para o ofício de governar.

Partindo-se desses enunciados, decerto que duas questões se nos aparecem, a saber: o que é esta "razão iluminada a guiar tudo a seus justos fins"e qual o elemento volitivo a ordenar a legislação?

Para encontrarmos a resposta, convém ter em nosso horizonte que esta é a época do despotismo esclarecido, ${ }^{14}$ do déspota iluminado. ${ }^{15}$ Nela, o ente estatal é concebido como um corpo invocado e mobilizado para a realização e o espraiar das regras que alcancem a felicidade dos povos. Nesse sentido, anotamos: "a ética racionalista (...) concebia a função do soberano como um serviço técnico prestado ao Estado, tendo-se tornado conscientemente num instrumento coadjuvante nesse sentido, instrumento que-comoenorme poder do monarca, embora muitas vezes contra a resistência do povo, dos estados e das igrejas

${ }^{12}$ Sublinhamos que a validade do direito caracterizava-se por seu aspecto formal.

${ }_{13}$ Para uma melhor e mais precisa definição conceitual do que sejam regras gerais, abstratas e formais, consignamos: a expressão geral relaciona-se ao fato da lei ser igual para todos, uma vez nāo mais existir a anterior diferenciação social entre nobres e plebeus, mas sim a existência de cidadãos; sāo abstratas as leis "porque só na abstraç̧ão é que pode haver dedução. Na verdade, só abstraindo do individual, do singular, do particular, é que pode pretender-se que a lei se aplique do mesmo modo a todos" (BRonzE: 1997, 324); enquanto que a dimensão formal caracteriza-se pela despreocupação do conteúdo material da própria lei, que somente determinava as "regras do jogo" e estabelecia a esfera de cada individuo em relação aos demais. Dentro dessa fronteira de atuação conformada pela lei, o indivíduo, dono de sua liberdade, pode administrar, dirigir seus interesses. ${ }^{14}$ Apenas com o intuito ilustrativo, elencamos alguns nomes que se encontram presentes no momento do despotismo esclarecido: Luis XIV e Luis XV, na França, Frederico II da Prússia, José II e LeOPOLdo II, representantes da monarquia austríaca, CATARINA II, na Rússia e em Portugal, D .José e D. MARIA I.

15 LuIS CaBRal de Moncada identifica que, diante do despotismo esclarecido, o Estado passa a ser um órgāo a "realizar e a propagar pela força, despoticamente, as luzes e os ditames do entendimento para a felicidade dos povos, numa visão toda simultaneamente, individualista, eudomonista e utilitária das coisas, do homem e da sociedade". 
-impôs mesmo aos juristas os seus novos padróes axiológicos"(WIEACKER: 1967,367). Com efeito, a autoridade e a razáo convergem para a figura do déspota esclarecido, a atuar diretamente na reforma da sociedade setecentista. $E$, quanto aos aspectos jurígenos do Iluminismo, identificamos duas posturas: uma referente ao direito natural, e de cunho racionalista; e outra, de caráter voluntarista, referindo-se ao direito positivo. As duas posturas complementam-se e, justapondo-as, forja-se uma síntese do direito: o dimanar, o derivar de uma expressão de vontade, posta em função de uma razão.

\section{Códigos JusRACIONALISTAS}

O fenômeno das codificações constituiu-se numa verdadeira revolução do pensamento jurídico. Suas conseqüências foram sentidas para muito depois de seu início. ${ }^{16}$ Inevitável nos parece a referência ao ano de 1804 , com a entrada em vigor do Code Civil. Contudo, salientamos que, antes mesmo dessa data, já haviam sido elaborados alguns códigos, como o prussiano, por exemplo.

O processo de codificação que ocupou o território europeu refletiu e expressou notadamente o espírito racionalizante da época, representando claramente o produto do que anteriormente mencionamos: a simbiose entre o poder e a razáo promovido pelo despotismo esclarecido. Buscava-se, por meio das codificações, a construção de um sistema completo, um corpo de leis perfeitas. Baseado em tais postulados, chega-se a outro, preocupado tão-só com aspectos formais: a submissão do intérprete à lei, registrando que esse postulado preocupava-se tão-só com aspectos formais.

As codificações notabilizaram-se como o espelho de uma cultura superior, evoluída, não só pelo estilo utilizado, mas, igualmente, se pensado pelo prisma do conteúdo. ${ }^{17}$ Ademais, representava um projeto de edificação, organização do Estado.

Os códigos da época - e descortina-se em nossa visão especialmente o da Prússia - denotam os preceitos caracterizadores do Iluminismo. A cega fé numa razão, instalada no homem, possibilitaria a existência de um direito totalmente justo e, portanto, conduziria o legislador a elaboração de regras que norteariam plenamente a sociedade, disciplinando, todas as situações possíveis. Importa ressaltar um efeito que transparece da crença jusracionalista: uma certa dificuldade imposta a um potencial avanço natural que um código pode ter, e que, muitas vezes, seu próprio autor desconhece. ${ }^{18}$ Outrossim,

\footnotetext{
${ }^{16}$ Basta, para isso, percebermos que a codificação, como um movimento autônomo, encontra-se historicamente situada no século XVIII, sendo suas influências claramente notadas na Escola da Exegese, nascida no século XIX, que espalhou seu sentido, em maior ou menor grau, até o nosso atual século. A propósito da Escola da Exegese, Chaim Perelman distingue três etapas de seu desenvolvimento: "uma fase de instauração, que começa com a promulgação do Código Civil em 1804 e acaba entre 1830 e 1840; uma fase de apogeu, que se estende até por volta de 1880; e finalmente, uma fase de ocaso que se cerra em 1889" (1988, 37).

17 Neste sentido, ver Franz WIEACKer, na sua obra intitulada História do Direito Privado Moderno, $2^{\mathrm{a}}$ edição, Lisboa: Fundação Calouste Gulbenkian, 1967.

${ }_{18}$ Precisamente esse entendimento encontramos exposto em Franz WIEACKER, op. cit., pág. 379.
} 
no período do direito natural estremado pela razão, a par da independência e da autonomia do legislador, desvela-se uma certa descrença frente à jurisprudência. E valemo-nos da expressão "certa descrença" não gratuitamente, pois alguns códigos admitiam a sua nãoplenitude, com a conseqüente possibilidade de uma integração - precisamente uma heterointegração. O campo, a esfera para a manutenção, mesmo que um tanto mais restrita, da jurisprudência, da atividade judicial, permanecia.

Nada obstante a importância dos códigos precedentes, gostaríamos de direcionar o foco de nossas apreciações ao Código Civil Francês de 1804. Originariamente, a promulgação desse código encontra suas raízes no umbral do período revolucionário. Destaca-se, de plano, duas idéias nucleares: a de uma nação una e indivisível e a imposição da substituição do "antigo particularismo feudal por um direito geral dos franceses baseadona razão"(WIEACKER: 1967, 386).

Essencialmente, salvo melhor juízo, a codificação francesa distingue-se das demais por não ser fruto daquele ethos racionalista - a prever como sendo função do soberano prestar um ofício técnico ao Estado-, fruto do despotismo esclarecido, mas por ter arrimos claramente iluminados por luzes acendidas pelo farol do movimento revolucionário e pela exponencial importância napoleônica. ${ }^{19}$ Contudo, o cariz revolucionário em nada afasta a indigitada obra - o Code Civil - da crença jusracionalista na lei escrita. Ao contrário, na esteira dos ensinamentos de MANUEL CALVO GARCíA, consignamos: "en este punto, para ser justos (y también precisos), quizá haya de reconocerse que el exponente máximo de esa fe absoluta en la letra escrita se encuentra en la Revolución francesa y no en la codificación propiamente dicha. (...). La Revolución francesa nace vinculada y proyecta sobre la realidad una auténtica fe en la letra escrita" $(1994,69) .{ }^{20}$ De fato, o que destacamos nesse parágrafo é, estrutural e espiritualmente, um código que se encontra colorido pelas fortes tintas da participação dos cidadãos e da então nova soberania popular conquistada.

De outra banda, impende salientar que os fatores caracterizadores do direito codificado influenciaram sobremaneira a metodologia jurídica. Assim, fruto das profundas transformações sociopolíticas da época - nomeadamente as ocorridas no século XVIII, o mobilizar de uma racionalidade formal, tanto na criação do direito quanto em sua aplicação, vincula-se, então, ao princípio da igualdade, que consagra este novo Estado

\footnotetext{
${ }^{19}$ Outro traço, não menos importante, de distinção entre os códigos nāo-revolucionários - como os bávaros e o austríaco, por exemplo - e codificação francesa, diz respeito a admissão às lacunas jurídicas, implicando um corte radical com a tradição anterior. Assim: "é certo que os códigos de Setecentos, ou moderno-iluministas não revolucionários (...) estavam longe, não obstante seu jusnaturalismo, de uma total ruptura com a tradição histórica, nem deixavam de admitir expressamente a sua incompletude, ao reconhecerem-se com lacunas(...). Outro tanto não acontecia com o Code Civil (...). Que tanto é dizer: um código que recusava a história e que, na sua axiomática racionalidade, se bastaria a si próprio." (CASTANHEIRA NeVES: 1995, 182).

${ }^{20}$ Para reforçar a idéia, o referido autor assevera que o fato de "plasmar por escrito los derechos con el fin de hacerlos reales y efectivos es una de las razones fundamentales del constitucionalismo, de la misma forma que el plasmar por escrito un orden político tiene bastante que ver con la creencia de que ello promueve su consolidación" (op. cit., 69). Aqui, para se evitar um equívoco juscoparatístico, há de se anotar que essa afirmação não traduz qualquer lei universal, pois há países que não apresentam a tradição de uma constituição escrita e, nem por isso, deixam de ter seus direitos fortemente consolidados..
} 
emergente. Decerto, a isonomia pensada na época restringir-se-ia a um escopo meramente formal, isto é, de uma mera igualdade formal perante a lei. Caracteriza-se o plano formal por dimensionar todos os cidadáos como submetidos aos mesmos procedimentos e órgáos jurisdicionais; as leis são postas para um sujeito em abstrato, não existindo uma particularização no que concerne ao destinatário da norma jurídica. Deste modo, todas as pessoas colocam-se como receptores das mesmas normas, merecendo e devendo, então, receber o mesmo tratamento também na aplicação da lei. Para tal exigência de igualdade ser implementada, mister se superar as contingências, as questōes pontuais que cada caso porventura apresentasse, buscando-se um método garantidor de uma certeza e segurança na aplicação da lei. A lei a ser codificada deveria, para tanto, além de escrita, ser clara, de tal maneira a dispensar a interpretação do juiz, objetivando a figura de um juiz autômato. É o postulado da abstração e generalidade tendo seu início. E o código, com sua pretensa plenitude oriunda, de uma razão universal e absoluta, "determina que la ciencia jurídica se convierta en ciencia del derecho positivo. A partir deste fenomeno, la ciencia jurídica deja de ser una ciencia creadora y pasa a ser una ciencia reelaboradora que hace del texto de la ley su objeto científico específico" (CALVo GARCía: 1994, 72)

\section{Corte Com a Tradição Jurídica - Communis Opinio Doctorum e o Direito} ROMANO

O primado da razão, além das alteraçóes já referidas, ocasionou profundas mudanças no tocante às fontes de direito, de sorte que, na Europa Setecentista, nasce um sentimento de distância em relação ao direito romano, sendo também objeto de crítica a communis opinio doctorum. ${ }^{21}$ A razão assume uma posição proeminente, primordial no quadro das fontes de direito. Com efeito, encontramos as seguintes posições: "há quem, embora sujeitando o direito romano ao crivo da Razáo, pense que vale, ainda, a pena submetê-lo a exame, com o fim de nele aproveitar o que mostre utilidade; há, enfim, quem pressupondo a completa historificação do direito romano, o estude, passe a expressão, como peça de museu, exemplificadora de uma particular e importante experiência jurídica passada" (GOMES DA SILVA: 1990, 341).

\footnotetext{
${ }^{21}$ Ressaltamos que a partir da entrada em vigor das Ordenaçōes Manuelinas, a Comum Opinião dos Doutores passara a ter valor de fonte de direito subsidiariamente em Portugal. Ademais, em todo o solo europeu, nesse mesmo período, a communis opinio doctorum é alçada à fonte de direito. Assim temos o parágrafo 1 do título V do Livro II da indigitada ordenação: "se o caso de que se trauta em practica nom for determinado por Ley do Reyno, ou Estilo, ou Custume suso dito, ou Leys Imperiaes, ou Santos Canones, entam Mandamos que se guardem as grosas de Acursio encorporadas nas ditas Leys quando por comum opiniam dos Doutores nom forem reprovadas; e quando por as ditas grosas o caso nom for determinnado, Mandamos que se guarde a opiniam de Bartolo nom embarguante que alguûs Doutores teuessem o contrario; saluo se a comum opiniam dos Doutores que despois delle escreueram, for contraira, porque a sua opiniam comunmente he mais conforme aa razam» (GoMes DA SILVA: 1990, 308).
} 
Por certo, tal posicionamento crítico alusivo à communisopinio doctorum parecenos plenamente de acordo, em coerência, com as novas exigências mobilizadas e impostas pelo postulado da razão. Senão, vejamos: ora, o edifício da communis opinio doctorum ergue-se alicerçado pela autoridade, a auctoritas, da ... opinião dos doutores. A propósito, temos como relevante o que diz a respeito MANUEL CALVO GARCíA, ao tratar da ciência jurídica medieval: "en cualquier caso, la figura del Doctor adquiere una relevancia especial en el nacimiento de la ciencia jurídica. El Doctor no es un interprete cualquiera. Es un interprete revestido de autoridad. (...). De hecho, se da por sentado que la autoridad de los Doctores era equivalente al respeto que se profesaba en el campo de la teologia a los padres de la Iglesia" (1994, 24-25 passim). E o pressuposto da autoridade da opinião transita no âmbito da dialética, mobiliza razóes prováveis, buscando uma verdade possível, plausível. Trata-se de um argumento dentre vários outros. Sabemos que o paradigma filosófico desses modernos tempos divorcia-se do conhecimento provável, e busca trabalhar com o que pode ser demonstrado, comprovado.

Nesse norte, a partir do já aqui referido RENĚ DESCARTES, com sua obra "ODiscurso do Método", segundo escólio do sociólogo português BOAVENTura Souza SANTOS, tudo o que pertencer ao campo do provável é tido por falso $(1989,111)$. Então, alça-se a razão como instância última para definir uma verdade, ou melhor, a verdade. $O$ verdadeiro ocupa o espaço do provável, da probabilidade. O conhecimento encontra-se lastrado por um ideal universal. Supóe-se a possibilidade de alcançar a verdade em todos os ramos do conhecimento humano: do mesmo modo que há verdades absolutas na área matemática, há de haver, igualmente, no campo jurídico. ${ }^{22} \mathrm{E}$, através da razão, permeada por um método, que se alcança o patamar da verdade. E o método é o demonstrativo que, para além da seara das ciências exatas, brota, vigorosamente, no terreno jurídico.

Tendo como pano de fundo essa ambiência, dá-se o aparecer de legislações que, expressa e explicitamente, reduzem a possibilidade de menção, citação de doutrinadores nas peças destinadas ao foro. Assim, em Urbino, pátria de RAFAEL, por obra do duque Francesco Maria II della Rovere, no período de 1613 e 1632, vigorara uma lei determinando, de modo taxativo, as fontes de direito disponíveis aos juízes e advogados. Seriam, em questões cíveis: o Corpus Iuris, assim como as obras de BÁRTOLO, BALDO, Paulo de Castro, Jasão de Maino, Alexandre Tartagni, João de Imola e, ainda, os estatutos e decretos do Estado. Nas controvérsias criminais, possibilitava-se as citações de Alberto de Gandino, Angelo Aretin, Egidio Bossi e Julio Claro (Gomes da Silva: 1991, 348). Contudo, algumas legislaçōes foram além da limitação, ou seja, acabaram mesmo por impedir, tornar defeso a citação dos autores, inclusive com a previsão de punição, sob a forma de suspensão das atividades, para os advogados ou juízes que porventura citassem ou adotassem as opinióes dos Doutores. ${ }^{23}$ Outro diploma legal a ser referido é o publicado por Fernando IV, em Nápoles, no ano de 1774, que dispunha o

\footnotetext{
${ }^{22}$ Sem embargo, era esta uma crença de DESCARTES: que o método, com resultado de tão bom êxito na realidade matemática, poderia, da mesma forma, ser lançado a outras searas da cultura humana. Nesse sentido, ver Russet: 2001, 278.

${ }^{23}$ Referimo-nos à Constituição da Sardenha, do ano de 1729.
} 
dever dos juízes de fundamentar suas decisões finais com base na legislação do Reino. Com isso, buscava-se elidir as opinióes dos Doutores, pois estas tornariam o direito dúbio, impreciso, e, por conseguinte, tendente à arbitrariedade.

Da orientação de tais legislaçóes claramente se depreende o espírito dominante na época: a crença de que as leis, expressão da razão universal a bem orientar os homens, condensavam todo o ideal de direito e, portanto, nada mais adequado do que seu mero aplicar. Assim, alcançar-se-ia a verdade existente no direito, suprimindo-se a lógica dialética, orientada pela possibilidade, pelo presumível.

Em Portugal, antes de se concretizar tal postura, é dizer, o eliminar da opinião comum dos doutores, ocorrido efetivamente com a lei de 18 de Agosto de 1769, batizada de Lei da Boa Razão, surgem alguns sinais atestando o primado da razão sobre a “opinião". Vejamos: em 1759, fora estabelecido que em cada escola houvesse um Diretor dos Estudos, e constava no estatuto deste Diretor o que segue: «e por quanto as discordoas provenientes na contrariedade de opiniōes, que muitas vezes se excitão entre os Professores, só servem de distrahilos das suas verdadeiras obrigaçōes, e de produzirem na Mocidade o espírito de orgulho e discordia; teráo Director todo o cuidado em extirpar as controversias, e de fazer que entre elles haja huma perfeita paz, e huma constante uniformidade de Doutrina; de sorte, que todos conspirem para o progresso da sua profissão, e aproveitamento dos seus discípulos" (GOMES DA SIlva: 1991, 350). Em 1760, criava o Rei D. JosÉ um Intendente Geral da Polícia da Corte e do Reino. ${ }^{24}$ Expressa o parágrafo $20^{25}$ dessa lei, com precisão, a idéia a ser desenvolvida nesta etapa do trabalho, uma vez que dita, determina o cumprimento literal, ipsis verbis, da mencionada lei, desprezando-se as opinióes dos juristas. Compete acentuar que, nessa época, a interpretação literal não era tida como um dos métodos interpretativos, e a função do juiz reduzia-se a um simples aplicador da lei escrita, conforme já tivemos a oportunidade de constatar.

Ora bem, assim como observamos, no período anterior ao Iluminismo, a interpretação do direito romano era baseada no elemento da autoridade. Nos tempos modernos, perde sua validade; seu sentido esvazia-se. Na verdade, há, no abrir da Idade Moderna, uma fragilidade, uma debilidade na lógica de proceder do pensamento jurídico, ou seja, uma insuficiência do pensamento, visando, a realização do direito. Diante dessa problemática, aparece o ideário do direito natural como uma alternativa. A propósito,

${ }^{24} \mathrm{O}$ cargo seria vitalício, e seu detentor exerceria suas atribuições com total jurisdição em matéria policial, "sôbre todos os ministros criminais e civís, para a êle recorrerem e dêle receberem as ordens nos casos occorrentes; dando-Ihe parte de tudo o que respeitasse à tranquilidade pública; $e$ cumprindo inviolavelmente seus mandados" (FORTUNATO DE ALMEIDA, in Poder e Instituiçōes na Europa do Antigo Regime, Fundação Calouste Gulbenkian, Lisboa:1984, pág.326 e 327). Para efeito de ilustração, o primeiro Intendente Geral da Polícia foi o desembargador INÁcIo FERREIRA SOUTO .

${ }^{25}$ Assim estava redigido tal parágrafo, na parte mais pertinente ao tema tratado: "pela informação que tive de que huma das causas que até agora impedirão a exacta e necessaria observancia das leis estabelecidas para a paz publica da Minha Corte, consistio em serem as mesmas Leis entendidas especulativamente pelas opiniōes dos Doutores Juristas, as quaes são entre si tão diversas como o costumão ser os juízos dos homens. E para que a segurança de meus Vassalos não fique vacillando na incerteza das sobredictas opiniōes: Ordeno que esta Lei, e as mais que por ella tenho excitado, se observem literal, e exactamente como nellas se contém sem interpretação ou modificação alguma, quaisquer que ellas sejão; porque todas prohibo e annulo." (grifo nosso). 
FRANZ WIEACKER sustenta que: “(...) a tradição do direito natural (...) é sempre chamada a terreiro quando uma ordem jurídica histórico-concreta perde a sua persuasão" $(1967,281){ }^{26}$ E assim proceder-se-á: os regramentos jurídicos nascem da própria natureza humana, e o homem, valendo-se da sua razão, há de encontrar o direito pleiteado pela sua própria natureza, é dizer, um direito natural.

Na época medieva, o direito natural assumiu um vinculação divina. Desponta então o posicionamento de São TOMÁs DE AQUINO, partindo de um conceito de inteligência divina para instituir a idéia do direito. No jusnaturalismo tomista, o direito natural, sancionado por Deus, continha uma verdade eterna. Essa postura passa a influenciar sobremaneira a chamada "Escolástica Espanhola"2?, que, inclusive, pensando in extremis e só para o efeito argumentativo, visto ser uma hipótese considerada absurda, cogita a existência de um direito natural até mesmo sem a existência de Deus. Entretanto, ainda que de cunho hipotético, o mero pensar de um direito independente da existência de Deus torna-se o ponto de partida para uma futura desvinculação do direito natural da até então dominadora idéia que estabelecia fortes liames entre o direito e a teologia.

Assim, surge Hugo Grócro como fundador do moderno jusnaturalismo, ${ }^{28}$ ao dizer que o direito natural o seria mesmo sem a existência de Deus. E isso não seria somente um simples argumento, tal qual visto pela Escola Peninsular de Direito Natural, mas sim uma proposição para um novo modelo de direito desligado da teologia. Consoante o magistério de PAUlO MEREA, GRócio teria elaborado "pela primeira vez um sistema de direito puramente secular. E, é êsse em grande parte o segredo de seu êxito; essa a razão por que toda a escolajusnaturalista reconheceu nêle o seu fundadore por que de facto podemos ver nêle o homem que, adentro da jurisprudência, abriu caminho ao iluminismo" $(1941,65)$. O direito passa a ser a expressão de uma verdade universal, independente mesmo da existência do próprio mundo. Em GRÓcio, encontramos a idéia de que "há um direito que antecede toda a vontade humana e divina e cuja validade é independente delas"e "assim como Deus nãopode evitar que dois e dois sejam quatro, também não pode fazer que o justo deixe de ser justo ou o direito direito" (apud CABRAL DE MONCADA: 1995, 162-163). Pelo exposto, adotamos os dizeres de PAULO MERÊA : “(...) Grócio foi um conservador da herança escolástica, o elo da cadeia que prende opensamento da Idade Média ao pensamento moderno" $(1941,67) .{ }^{29}$

\footnotetext{
${ }^{26}$ Cremos, contudo, que esta observação tem seu sentido tão-somente se pensada para o referido momento histórico, considerando à época que fora feita. Porque entendemos hoje, diante de qualquer crise metodológico-jurídica, ou ainda, conforme o autor, quando uma "ordem jurídica histórico-concreta perde sua persuasão", não será o jusnaturalismo a alternativa mobilizada, tanto por seus pressupostos, quanto a sua inerente a-historicidade, já terem sido alvo de severas e inapeláveis críticas.

${ }^{27}$ Também chamada de Escola Peninsular de Direito Natural. Desenvolveu-se na Península Ibérica, nomeadamente na Espanha. Caracterizava-se por uma postura jusnaturalista, com uma visão teocêntrica do direito e do Estado, considerando o poder como essencialmente de origem divina. Como nomes proeminentes temos: Domingos Soto, Gabriel Vasquez, Luis de Molina e Francisco Suarez.

${ }^{28} \mathrm{Nada}$ obstante a referência acima, registramos uma certa polêmica sobre se efetivamente teria sido GRócio o "pai" do direito natural moderno, ou apenas o último elo da Escolástica. Nesse sentido, ver WELZEL: $1957,162$.

${ }^{29}$ Assim também o consideram luis Cabral de Moncada e Franz Wieacker. Entre nós, Miguel Reale assim se expressa: "Na realidade, Grócio é um homem de transição, como que dominando duas épocas, enxertando no tronco do pensamento anterior as diretrizes do pensamento novo" $(2000,104)$.
} 
Portanto, endereça-se o pensamento jurídico ao desvendar das regras universais e comuns aos homens. Abre-se mão da teologia, alçapremando-se a razão como instrumento para alcançar tal desiderato. E o moderno direito natural será o forjado pelo respectivo regramento fruto da descoberta da razão dos homens.

Não poderíamos encerrar este item de nosso opúsculo, contudo, sem mencionarmos a posição destinada ao direito romano na verdadeira encruzilhada com o direito natural moderno. $\mathrm{E}$, assim, pensamos no usus modernus pandectarum, que estudaria o direito romano tão-somente nos casos adequados às necessidades apresentadas na época. De fato, significava que, se determinadas orientaçóes legais romanas pudessem ser objeto de um uso moderno, o seriam por estar em conformidade com a razão. Seria, ao fim e ao cabo, resumidamente, uma nova e atualizada prática do direito romano.

\section{O Período Iluminista no DireIto Português}

Os efeitos do período iluminista no direito de Portugal começam a aparecer graças ao trabalho desenvolvido por portugueses que viviam fora de seu país - os estrangeirados - e almejavam que Portugal, igualmente, partilhasse as notáveis mudanças, senão rupturas, sobrevindas no mundo europeu. E como nome de proa surge Luís ANTóNIO VERNEY, um padre lusitano que rumou para Roma no ano de 1736, com a tarefa de estudar em solo italiano. Lá sempre vivera, tendo falecido em 1792 (CABRAL DE MONCADA: $1949,07)$. Pois VERNEY colaborara direta e incisivamente para o implementar da agenda iluminista em sua terra natal, na época sob o reinado do D. José I, e seu forte Ministro, o MARQUÊS DE POMBAL. ${ }^{30}$

Na pauta da época, figurava, segundo palavras do professor MÁRIO DE ALMEIDA COsTA; "uma supersticiosa hostilidade à Escolástica (...): um direito natural fundado na razão humana; o horror aos moldes tradicionais do direito romano, agora só aceite na medida do "uso moderno"; uma forte tendência para a personalização do direito pátrio(...); e, também, uma acrisolada simpatia pelo próprio direito positivo vigente nas naçóes estrangeiras" (1961, 38 e 39).

O ponto de início deflagrador do processo que marca em Portugal um novo período, rompendo com os paradigmas culturais anteriores, pode ser assinalado com a publicação, em 1746, da obra Verdadeiro Método de Estudar, da lavra de VeRNEY. Podemos aquilatar sua fundamental importância atentando para os comentários feitos a seu respeito pelos eminentes autores, já aqui citados, LUís CABRAL DE MONCADA e MáRIO DE ALMEIDA COSTA, respectivamente: "(...) livro revolucionário que marcou em Portugal o início de uma nova época em Pedagogia e numa boa parte da nossa mentalidade cultural. Direi sòmente que o novo livro rebentou no País como uma bomba" $(1949,17)$ e "todo o livro, redigido por um

${ }^{30}$ Em relação ao vínculo entre Luis ANTÓNIo VERnEY e o governo português de então, ver a pequenagrande obra de Luís Cabral de Moncada, Um lluminista Português do Século XVIII - Luís António Verney. 
homem com longa residência no estrangeiro e dotado de um senso crítico pouco vulgar, constitui pesado libelo que caía em cheio sobre muitos aspectos da mentalidade da época e dos diversos ramos do ensino em Portugal"' (1961,39). Não menos reveladoras do mérito da indigitada obra são as palavras do professor RUI DE FIGUEIREDO MARCOS, em sua dissertação de mestrado em Ciências Jurídico-Históricas, na Universidade de Coimbra. Ei-las: "todo o saber represado, que tremeluzia serenamente, estalejou, a breve trecho, numa tempestade renovadora. Faiscaram os intelectuaisortodoxos quando aproou, em Lisboa, o Verdadeiro Método de Estudar. (...) acabou por circular e a mensagem reformadora de um iluminista obcecado como Luís António Verney haveria de transformar-se em credo nacional"'(1990, 15).

Um combate aos métodos empregues pela Escolástica, baseados na autoridade das opiniōes, na extrema consideração às codificações, na necessidade de estudar a real fonte do Direito - a Filosofia -, na relevância do direito nacional, no destaque do direito romano no que tivesse utilidade e servisse para a época, é dizer, o usus modernus pandectarum, a importância do conhecimento da história, universal e romana, propugnava, entre outras idéias, VERNEY. A razão era vista como igual e imutável em todos, de modo a não se alterar com o tempo. Enfim, uma verdadeira cartilha, onde resplandecia o pensamento iluminista, assente no racionalismo e historicismo tão conformadores da época.

Expressivo destaque e fundamental importância tivera a lei de 18 de Agosto de 1769, a chamada Lei da Boa Razão. Embora com observações de caráter sintético, podemos dizer, a respeito do referido diploma legal, que suas linhas acabam por encetar um iter de marcadas alterações concernente às fontes de direito. Nesse sentido, "no auge do vigor pombalino, a Lei de 18 de Agosto de 1769 fez ruir, de um só golpe, todo o edifício do direito subsidiário herdado do Código Filipino" (MARCos: 1990, 157). Estabelece, em seu parágrafo $14^{31}$, requisitos para que o costume fosse válido como fonte de direito. Tais eram: ser conforme à boa razão, não ser contra legem, e ter mais de cem anos de existência. Ainda quanto as fontes nacionais, há medidas tomadas que atingem os "estilos da Corte", restritas apenas aos estabelecidos e aprovados por meio dos "Assentos na Casa de Suplicação".

Com efeito, vale ressaltar que, autonomamente, os estilos da Corte sofrem um esvaziamento, pois apenas valeriam como fontes se recepcionados e aceites pelos assentos, conforme destaca o professor RuI MARCos, (op. cit. pág. 156, nota 258). Acentua-se, outrossim, que referente ao direito subsidiário recepcionado das Ordenaçóes Filipinas, restou o direito romano. $\mathrm{E}$, mesmo em relação a ele - o direito romano -, incidia a luz da razão jusnaturalista. Explica-se: em face dos casos omissos, recorrer-se ia ao direito romano, desde que enquadrado na moldura da boa razão. Mas enfim, o que seria a boa razão

\footnotetext{
${ }^{31}$ Parágrafo 14 da Lei da Boa Razão: “(...) os Estilos da Corte devem ser somente os que se acharem estabelecidos, e aprovados pelos sobreditos Assentos da Casa da Suplicação: e que o costume deve ser somente o que a mesma Lei qualifica nas palavras, longamente usado, e tal, por direito se deva guardar: cujas palavras Mando que sejão sempre entendidas no sentido de concorrerem copulativamente a favor do costume, de que se tratara, os tres essenciaes requisitos: de ser conforme às boas razões, que deixo determinado que constituão o espírito de Minhas Leis: de não ser a ellas contrario em cousa alguma: e de ser tão antigo que exceda o tempo de cem annos(...)".
} 
tantas vezes aludida na lei? A resposta encontra-se no próprio corpo legal. Boa Razáo, consiste "nos primitivos princípios, que contém verdades essenciais, intrínsecas, inalteráveis, que a ethica dos mesmos Romanos havia estabelecido e que a Direitos Divinos e Natural formalisarão para servirem de regras Moraes, e Civis entre o Christianismo: ou aquella boa razão, que se fund a nas outras regras que de unanime consentimento estabeleceo o direito das gentes para a direcção e governo de todas as Naçōes civilizadas: ou aquella boa razão, que se estabelece nas Leis Políticas, Economicas, Mercantis e Marítimas que as mesmas Naçōes Cristãs tem promulgado com manifestas utilidades (...)".

Respeitante às questôes sobre matérias econômicas, mercantis, marítimas e políticas, não encontrariam respostas coerentes se buscadas no direito romano. $\mathrm{E}$, em caso de lacuna do direito português, recorrer-se-ia às legislações existentes em outros países do continente europeu, segundo a própria Lei da Boa Razão estabelecia. Quanto às glosas de ACúRSIO e a Bartoli opinio, recepcionadas nas Ordenações Filipinas, tem-se agora uma proibição, tanto de suas alegações quanto de suas aplicações judiciais, por não serem tidas e havidas em consonância com às boas razões. ${ }^{32}$

Destacamos, todavia, um paradoxo, uma contradição entre o que buscava o espírito da época, consagrado na Lei de 18 de Agosto de 1769, e o que ocorria na prática. Porque ao pretender elidir uma certa incerteza oriunda da flexibilidade, da plasticidade dos argumentos opinativos anteriormente utilizados, acabou por trazer à superfície outra incerteza: a que nasceu do confronto das prescriçōes do direito romano, mobilizadas como direito auxiliar, com a dita boa razão.

Fato assaz importante, ocorrido no período setecentista, em Portugal, foi a reforma de seu ensino jurídico. E, seguindo uma ordem cronológica, temos, em 1770 , a criação de uma comissáo - Junta de Providência Literária - encarregada de proceder a um exame sobre os motivos causadores de um decréscimo no ensino universitário. Fruto dos trabalhos operados pela comissão, surge, no ano de 1771, o Compêndio Histórico do Estado da Universidade de Coimbra. Nessa peça, aos jesuítas foi atribuída toda a sorte de males ensajadores da decadência da Universidade, criticando-se seu sistema de ensino. No campo do direito, apontava para o estudo da história jurídica e da história geral, bem como a necessidade do estudo das línguas latina e grega, da retórica, da lógica, da autêntica Metafísica e do conhecimento do direito natural (GOMES DA SIIVA: 1991, 365-366). O compêndio ainda indicava que autores deveriam servir de base para o estudo do direito, como Pufendorf, Hugo Grócio, Hackmann, Barbeirac e Carlos António Martin, entre outros. Na continuação, no ano de 1772, surgem os novos Estatutos da Universidade de Coimbra. Seria o fecho, o remate do processo iniciado em 1770 com a referida Junta de Providência Literária.

\footnotetext{
${ }^{32}$ Assim dispunha o parágrafo 13 da lei: “(..) que as glosas e opiniões dos sobreditos Accursio e Bartholo não possão mais ser allegadas em juizo nem seguidas na practica dos julgados; e que antes muito pelo contrário em hum e outro caso sejāo sempre as boas razões assim declaradas, $e$ não as authoridades daquelles, ou de outros similhantes Doutores da mesma escola as que hajāo de decidir no foro os casos ocorrente".
} 
Ao fim e ao cabo, o que se pretendia era sintonizar a formação universitária com os novos padrões da época, e este é o reflexo dos novos estatutos: a influência do direito natural moderno. A reforma produzida no ensino universitário opunha-se frontalmente ao direito ensinado pelos jesuítas. Alça-se a Universidade e sua ambiência em conformidade com a visão moderna da época. $E$, para não correr nenhum risco de o antigo método de ensino continuar sendo aplicado, os lentes proprietários que exerciam seus ofícios não permaneceram em suas funçōes.

Como exemplo de novidade trazida pelos novos Estatutos da Universidade, mencionamos a nova cadeira, comum às faculdades de leis e cânones, de Direito Natural Público Universal e das Gentes. Importa ressaltar, igualmente, que constava dos novos Estatutos o método de ensino a ser utilizado. E este seria o "sintético-demonstrativocompendiário", onde o professor deveria "dar uma imagem geral da disciplina através da redução da matéria a um conjunto doutrinal e sistemático, subordinando a evolução expositiva a uma linha de crescente complexidade" (MARCOS, 1990, 169).

Cumpre-nos gizar, por fim, que essas reformas efetivadas na Universidade de Coimbra produziram suas influências no Brasil, como não poderia deixar de ser. Isso se deu porque vários brasileiros, no período entre 1772 e 1820, formaram-se nessa tradicional casa. Foram precisamente 469 brasileiros formados no campo jurídico. Muitos dos quais colaboraram como professores dos pioneiros cursos de direito criados no Brasil, segundo informaçóes presentes na Tese de doutoramento intitulada "A Influência da Universidade de Coimbra na Formação da Nacionalidade Brasileira", apresentada na Faculdade de Letras da Universidade de Coimbra, em 1996, pela professora RUTH MARIA GAUER. E aqueles nossos conterrâneos trouxeram d'além mar, para o solo brasileiro, a perspectiva do moderno direito natural, aprendido na excelência dos bancos acadêmicos da Universidade de Coimbra.

\section{APRECIAÇÕES FINAIS}

Por certo, as ponderações e os registros assentes neste trabalho não têm o caráter, e nem a pretensão, de esgotar os assuntos desenvolvidos. Longe disso! Entrementes, acreditamos, modestamente, ter descortinado os aspectos principais da temática proposta, tendo-se em vista o indicado na peça introdutória.

Sem embargo, podemos, em sede de últimas considerações, perceber a importância da época ora analisada, não só para o direito, senão que para toda a esfera da vida cultural do homem.

Novos paradigmas foram criados, afastando-se por inteiro as estruturas anteriores. O direito natural, existente desde os tempos mais remotos - e, para tal, basta lembrarmonos de SóFOCLES e o drama de sua ANTíGONA - com sua existência confirmada no período da Idade Média, vê-se completamente renovado, (re)estruturado. Deixa de ser transcendente para ser imanente ao ser humano, que apresenta uma nova visão do mundo 
e de si próprio. Uma nova ética, racional e afastada da teologia, é fundada. A fórmula do contrato social ganha corpo, na busca da garantia e tutela dos interesses individuais.

Um novo método repousa nas águas do direito, que se vê convertido a uma ciência demonstrativa. Apregoa-se um direito atemporal, eterno e imutável. E o direito romano, via usus modernus pandectarum, experimenta o molde do direito natural racionalista.

Em Portugal, os novos ventos chegam, basicamente, graças à obra de Luís ANTóNIO

VERNEY. A Lei da Boa Razão, influenciada por esse autor, inaugura a modernização do direito português, sendo posteriormente complementada pelos novos Estatutos da Universidade de Coimbra.

Enfim, chega a hora de concluir o trabalho. E, como quem receoso por navegar em águas profundas mantém-se próximo da costa, encontrando como seu destino um porto seguro no final da jornada, julgamos ter encontrado o nosso: a ponderação acerca de alguns aspectos do período moderno-iluminista e suas influências no direito. 


\section{Bibliografia}

ALMEIDA, Fortunato de. Organização Político-Administrativa Portuguesa dos sécs. $X V I I$ e XVIII, in Poder e Instituiçōes na Europa do Antigo Regime. Lisboa: Fundação Calouste Gulbenkian, 1984.

ALMEIDA COSTA, Mário Júlio. História do Direito Português. Coimbra: Almedina Editora, 1989.

. Romanismo e Bartolismo no Direito Português, em Boletim da Faculdade de Direito da Universidade de Coimbra, vol. XXXVI, ano: 1960

ARENDT, Hannah. La Condición Humana, 3ª reimpressão. Barcelona: Paidós, 1998.

ASTUTI, Guido. OAbsolutismo Esclarecido em Itália e o Estado de Polícia, em Poder e Instituiçōes na Europa do Antigo Regime. Lisboa: Fundação Calouste Gulbenkian, 1984.

BAPTISTA PEREIRA, Miguel. Modernidade e Tempo: para uma leitura do discurso modemo. Coimbra: Editora Livraria Moderna, 1990.

BARCELLONA, Pietro. Estado de Derecho, Igualdad Formal y Poder Económico: apuntes sobre formalismojurídico yorden económico. Anales de la Catedra Francisco Suares, no 29, ano 1989, página 45 a 62 .

BRECHT, Bertold. Brecht-Selecçãode Poesias, Textos e Teatro, 2ª ed. Lisboa: Ediçōes Dinossauro, 1998.

BRONZE, Fernando José Pinto. Apontamentos Sumário de Introdução ao Direito. Coimbra: Coimbra, 1997. 1995.

CABRAL de MONCADA, Luís. Filosofia do Direito e do Estado, Coimbra: Coimbra, . Conceito e Função da Jurisprudência Segundo Verney. Boletim do Ministério da Iusticia, № 14 , Setembro, ano: 1949.

CALVOGARCIA, Manuel. Los Fundamentos del MétodoJurídico: unarevisión crítica, Madrid: Tecnos, 1994.

CASSIRER, Ernst. A Filosofia do lluminismo. $3^{\mathrm{a}} \mathrm{ed}$. trad. Álvaro Cabral. Campinas: Unicamp, 1997. 1983.

CASTANHEIRA NEVES, António. OInstituto dos Assentos, Coimbra: Coimbra, 1976.

1995. . Curso de Introdução ao Estudo do Direito, Coimbra: Coimbra, . Escola da Exegese, em Digesta, 2o volume, Coimbra: Coimbra,

COING, Helmut. Derecho Privado Europeu. trad. Antonio Pérez Martín. Madri: Fundación Cultural del Notariado, 1996.

FASSÒ, Guido. Storia della Filosofia del Diritto-l'età moderna. $2^{2}$ volume. Roma: Laterza, 2001.

FRYDMAN, Benoît e HAARSCHER, Guy. Philosophie du Droit. Paris: Dalloz, 1998. 
GAUER, Ruth Maria Chittó. A Influência da Universidade de Coimbra na Formação da Nacionalidade Brasileira, Tese de Doutoramento apresentada na Faculdade de Letras da Universidade de Coimbra. ano: 1996.

GOMES DA SILVA, Nuno J. Espinosa. História do Direito Português, $2^{\underline{a}}$ ed. Lisboa: Fundação Calouste Gulbenkian, 1991.

HAZARD, Paul. OPensamentoJurídico Europeu no SéculoXVIII. Lisboa: Presença, 1989.

HESPANHA, António Manuel. Poder e Instituições na Europa do Antigo Regimecolectânea de textos. Lisboa: Fundação Calouste Gulbenkian, 1984.

LAFER, Celso. A Reconstrução dos Direitos Humanos. $3^{\text {a }}$ reimpressão. São Paulo: Companhia das Letras, 1999.

LYOTARD, Jean-François. O Pós-Moderno Explicado às Crianças, $3^{\mathfrak{a}}$ ed. Lisboa, Dom Quixote, 1999.

MARCOS, Rui Manuel de Figueiredo. A Legislação Pombalina, em Suplemento ao Boletim da Faculdade de Direito da Universidade de Coimbra, vol.XXXIII. Coimbra, 1990.

MEREA, Paulo. Suárez, Grócioe Hobbes. Coimbra: Armênio Amado Editor, 1941.

ORTEGA, Manuel Segura. La Racionalidad Jurídica. Madrid: Tecnos, 1998.

PERELMAN, Chaim. La Logica Jurídica y la Nueva Retorica. Madrid: Editora Civitas, 1988.

REALE, Miguel. Horizontes do Direito e da História. $3^{\text {a }}$ ed. São Paulo: Saraiva, 2000.

RUSSEL, Bertrand. História do Pensamento Ocidental. 5a ed. trad. Laura Alves e Aurélio Rebello. Rio de Janeiro: Ediouro, 2001.

SANTOS, Boaventura Souza. Introdução a uma Ciência Pós-Moderna, 5ª ed. Porto: Afrontamento, 1988.

WELZEL, Hans. Derecho Natural y Justicia Material. Madrid: Aguillar, 1957.

WIEACKER, Franz. História do Direito Privado Moderno, 2ª ed. Lisboa: Fundação Calouste Gulbenkian, 1967. 